\title{
Divine Persons in Genesis:
}

The Theological Implications

\section{William D. Barrick}

The Master's Seminary, Sun Valley, CA 91352, USA

wbarrick@tms.edu

\begin{abstract}
Beginning with its third word, the book of Genesis reveals that God (בי:הexists and that He created the heavens and the earth. The seventeenth

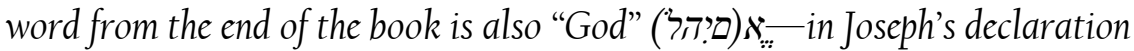
that God will provide for the descendants of his father Israel. Few exegetes would argue today that the plural form of 3 . divine persons - and rightly so. However, evidence exists within the text of the first book of Moses that might indicate a distinction of persons in the Godhead. For example, both Genesis 1:2 and 6:3 seem to refer to the Spirit of God. Other statements in the text of Genesis appear to mention more than one divine person named Yahweh (19:24). Some references involve a person identified as the "angel/messenger of Yahweh" (e.g., 22:11). Was this individual the same as one of the "three men" who appeared to Abraham (18:2) and before whom Abraham stood (18:22)? Is he a person of the Godhead? In addition to these more direct and perhaps less abstract references to a divine person, Genesis includes several first person plural statements ("us" and "our") spoken by a divine person (1:26; 3:22; 11:7). Are these references best explained as multiple divine persons, some sort of plural of majesty, or some council of spirit beings other than divine? What is the exegetical evidence? What are the implications theologically regarding either a plurality of divine persons or even a limitation to three such divine persons? Furthermore, how do these implications affect the way we understand ancient human conceptions of God, His person, His attributes, and His work from Adam to Joseph?
\end{abstract}

Article History:

Received 26 March 2020

Accepted 15 July 2020

Keywords:

Genesis,

Plurality,

Persons,

Divine

\section{Introduction}

Let's commence this study by looking at some general principles with which to approach the topic of the Trinity in the OT generally. First, we must recognize that the revelation God provides in the OT represents the early stages of progressive revelation completed by the NT. At each stage of revelatory development, the biblical text clarifies and expands theological truths. Second, the wisest course of interpretive analysis attempts to interpret the biblical text with its chronological development in mind. In other words, we need to avoid interpreting Genesis by means of Isaiah or Isaiah by means of the NT. Third, each text must stand by itself in its own context. What did the original writer intend and how did the original recipients understand it? 
John Feinberg suggests that we need not "lose anything of significance to the doctrine of the Trinity"1 in the OT. In fact, he concludes that "the observant OT saint" could have observed clues in the OT texts that indicated "that there is more to say about God than just that there is one God and Yahweh is his name."

Although a plurality within the Godhead might be implied by the OT, that does not mean that the OT believer would ever speak of a triune God, nor would he formulate the plurality as Father, Son, and Holy Spirit per se. One note of caution, however-I am not saying that no OT believer ever referred to God as Father (cf. Ps. 89:26; Isa. 63:16; 64:8; Jer. 3:19; Mal. 2:10) or as Son (cf. Ps. 2:7, 12; Prov. 30:4) or as Holy Spirit (cf. Ps. 51:11; Isa. 63:10, 11). ${ }^{3}$ The individual titles might well be found somewhere within the OT's progressive revelation, but the three are never put together the way they are in Matthew 28:19, for example. Likewise, I am not saying that no OT text ever speaks of multiple persons by means of differentiating divine titles.

Some theologians express extreme skepticism regarding any concept of the Trinity in the OT and even question its existence in the Gospel narratives. ${ }^{4}$ A popular pamphlet on the Trinity only refers to OT texts to demonstrate the deity of Christ, but provides no indication at all that the OT itself testifies clearly to a plurality of persons in the Godhead. ${ }^{5}$ Have they correctly understood the biblical witness? Scripture alone contains the revelation of the doctrine of the Trinity—natural revelation provides no key or clue to this major article of Christian faith. Perhaps Chafer's observation summarizes the reason why some theologians fail to see the Trinity in the OT: "No argument has been advanced against the Trinitarian

1 John S. Feinberg, No One Like Him: The Doctrine of God, Foundations of Evangelical Theology (Wheaton, IL: Crossway Books, 2001), 445.

2 John S. Feinberg, No One Like Him, 445.

3 Such texts, being outside Genesis, will not be analyzed in this paper. For sympathetic statements about these texts, see Feinberg, No One Like Him, 451-56. It must be noted, however, that theologians sold out to higher criticism and the Documentary Hypothesis have to deny any concept of divine plurality in the OT, since they normally date Gen 1 to at least the sixth century B.C., a time parallel with the so-called Deutero-Isaiah; see Walter Brueggemann, Genesis, Interpretation (1982; repr., Louisville, KY: Westminster John Knox Press, 2010), 24-25.

${ }^{4}$ E.g., R. W. L. Moberly, The Bible, Theology, and Faith: A Study of Abraham and Jesus, Cambridge Studies in Christian Doctrine (Cambridge, UK: Cambridge University Press, 2000), 236, "a Trinitarian theology must remember always to keep the Old Testament and gospel narratives in the foreground. Trinitarian theology always tends to locate in eternity that which was achieved in time." Although Broughton Knox, The Everlasting God (Kingsford, Australia: Matthias Media, 2009), 67 believes that the Gospels do reveal the Trinity, he is convinced that the doctrine of the Trinity "arose from the Christian experience of God in Jesus Christ and which was taught indeed by Christ himself." In other words, Knox seems to deny that the OT reveals any plurality of divine Persons.

${ }^{5}$ Robert M. Bowman, Jr., et al., The Trinity (Torrance, CA: Rose Publishing, 1999). 
conception other than that it does not conform to the limitations of the mind of man." ${ }^{6}$ In other words, rejection of the Trinity in the OT stems from the fact that some theologians have difficulty allowing the writers of the OT (within their supposedly very primitive ANE environment) the ability to write of sophisticated theological concepts supposedly originating with Christianity in the NT. Usually, these theologians buttress their line of reasoning with constant appeals to a history of religion and to a documentary view of multiple editors for individual books of the OT.

\section{Discussion and Result}

\section{From the Beginning}

Genesis 1:1-2 speaks of more than just the act of creation. The text identifies the Creator as "God" and immediately thereafter indicates the possibility of another person of the Godhead at work: "the Spirit of God hovered over the surface of the waters." The phrase "Spirit of God"

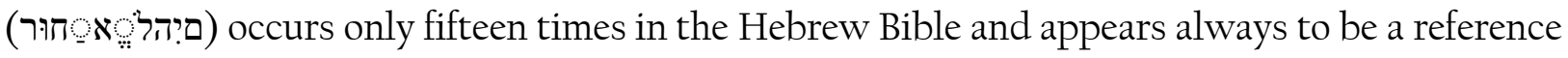
to a person, not a wind. In addition, מליה onever occurs as an adjective in the Creation account-it always refers to God. ${ }^{8}$ The evidence is so overwhelming that Hildebrandt reaches a conclusion commensurate with that of Moltmann regarding the personhood of the Spirit of God: "The personhood of God the Holy Spirit is the loving, self-communicating, out-fanning and out-pouring presence of the eternal divine life of the triune God." ${ }^{9}$ However, Hildebrandt then warns that taking this too far might lead to "speculative intrusion into the OT references," 1969), 1:274.

${ }^{6}$ Lewis Sperry Chafer, Systematic Theology (1947; repr., Dallas: Dallas Seminary Press,

7 Examples of this mode of thinking can be seen in extensive entries on רine (rûah, "S/spirit") in the less evangelical theological dictionaries: S. Tengström and H.-J. Fabry, "רוּn "חîh," in Theological Dictionary of the Old Testament, 16 vols., ed. by G. Johannes Botterweck, Helmer Ringgren, and Heinz-Josef Fabry, trans. by David E. Green (Grand Rapids: William B. Eerdmans Publishing Co., 2004), 13:365-402; R. Albertz and C. Westermann, "רוּ̣ rûah spirit," in Theological Lexicon of the Old Testament, 3 vols., ed. by Ernst Jenni and Claus Westermann, trans. by Mark E. Biddle (Peabody, MA: Hendrickson Publishers, 1997), 3:1202-20.

8 See Bruce K. Waltke, Genesis: A Commentary, with Cathi J. Fredricks (Grand Rapids: Zondervan, 2001), 60 (he also takes 6:3 as a reference to the Spirit of God as person; ibid., 117) and Wilf Hildebrandt, An Old Testament Theology of the Spirit of God (Peabody, MA: Hendrickson Publishers, 1995), 18.

9 J. Moltmann, The Spirit of Life: A Universal Affirmation, trans. by M. Kohl (London: SCM, 1992), 289 cited by Hildebrandt, An Old Testament Theology of the Spirit of God, 90. Gordon J. Wenham, Genesis 1-15, WBC 1 (Waco, TX: Word Books, Publisher, 1987), 17 agrees even while adopting the translation "'the Wind of God' as a concrete and vivid image of the Spirit of God." 
since the full development of the personhood of the Spirit of God awaits the NT revelation. ${ }^{10}$ This hesitation to make the commitment to seeing a divine person as "the Spirit of God" in the second verse of Genesis arises even among some of the strongest evangelical theologians. Merrill, for example, concludes that "The Spirit is to be understood here as an effect of God and not yet, as in New Testament and Christian theology, the third Person of the triune Godhead." Why the disagreements and even the hesitation to identify "the Spirit of God" in Genesis 1:2 as a person of the Godhead? Part of the resistance comes from the thinking that the interpreter must give due recognition to the ANE setting for the writing of Genesis and its Creation account. $^{12}$ Is that how we must read Genesis? Must we limit ourselves to the way that pagan, unbelieving, idolatrous ANE cultures viewed God (or, gods)? To yield to this hermeneutic requires one to degrade and even destroy the significant difference between genuine believers in the true God and those who ridicule them for their faith. Their worldviews are (and were) very different. Their value systems are opposed. A rough equivalent in our own day would be to insist that future readers of evangelical books should read them as though evangelicals have adopted the prevailing worldview or Zeitgeist - that our theology and morality actually coincide with non-Christian philosophy and (im)morality in the twenty-first century. If we would scream, "Foul!," so would the OT writers. Many who write as Hildenbrandt does only intend that we recognize that the OT writers are reacting to and interacting with the unbelieving culture of their day, not adopting the beliefs expressed by pagan myths. However, it doesn't always come out sounding or smelling that way, especially when someone insists that there is no way that "the Spirit of God" in Genesis 1:2 could be a person of the Godhead, because such a concept was totally foreign to the ANE cultures among whom the Hebrew writers dwelt.

One must also look at Genesis 6:3 where God refers to "My Spirit." Hildebrandt's treatment of this text detours into later revelation before reaching a conclusion. He seeks to place the reference in a context of divine judgment as expressed throughout the OT. He still comes to a result identifying the Spirit as a personal being, but not as independently as the decision he made in $1: 2{ }^{13}$

${ }^{10}$ Hildebrandt, An Old Testament Theology of the Spirit of God, 90.

${ }^{11}$ Eugene H. Merrill, Everlasting Dominion: A Theology of the Old Testament (Nashville, TN: B\&H Publishing Group, 2006), 102-3.

12 Hildebrandt, An Old Testament Theology of the Spirit of God, 3.

13 Hildebrandt, An Old Testament Theology of the Spirit of God, 83-91. Unfortunately, Mathews, Genesis 1-11:26, 332-33 fails to identify which view he himself prefers out of the three views he describes. Wenham, Genesis 1-15, 141 understands $6: 3$ as a reference to "the 


\section{Plural Nouns and Pronouns}

The Hebrew מיהלא ('elohim) does not suffice as proof of the Trinity. The same noun can be used of pagan gods like Baal and Ashtoreth (cf. Judg 8:33; 1 Kgs 11:5; 2 Kgs 1:3) — we would resist considering such plurals an indication of a trinitarian plurality of persons within Ashtoreth or Baal. The Hebrew text normally uses singular verbs and adjectives with מיהלא in reference to the one true God (e.g., Gen 1:1). It is so characteristic that any departure from that practice stands out as unusual and in need of careful evaluation. Therefore, passages such as Genesis 20:13 and 35:7 might benefit from a closer look due to their use of a plural verb with יםיהלא.

Theologians and exegetes can build a weightier case by examining the use of plural pronouns together with the identifications of distinct persons in the Godhead. Three passages using first person plurals punctuate the Genesis accounts of the creation, fall, and distribution of mankind on the earth $(1: 26 ; 3: 22 ; 11: 7)$. Whether these plurals are taken as plurals of majesty, plurals of self-address (deliberation ${ }^{15}$ ), potentially ${ }^{16}$ Trinitarian plurals, or references to a council of spirit beings, the references draw attention to the significance of the events with which the text associates them. ${ }^{17}$ These three texts mark notable events pertinent to a proper theological

life-giving power of God, . . . It is called the 'breath of life' (2:7) or 'the spirit of life' (6:17; 7:15)." Wenham's view agrees with that of Claus Westermann, Genesis 1-11: A Commentary, trans. John J. Scullion (1984; repr., Minneapolis, MN: Augsburg Press, 1990), 374.

14 Feinberg, No One Like Him, 449. See Gordon J Wenham, Genesis 16-50, Word Biblical Commentary 2 (Dallas: Word Books, Publisher, 1994), 73, 321 for explanations not contributing to any view of the plurality of persons in the Godhead. Michael S. Heiser, "Should מיהלא ('ělohhîm) with Plural Predication Be Translated 'Gods'?" Bible Translator 61, no. 3 (July 2010): 124 identifies only six such occurrences in the Hebrew Bible (although in the article he adds a seventh, Gen 31:53; ibid., 133). Heiser concludes that such plural verbs with םיהלא probably could be taken as references to a divine council (ibid., 136). The matter involves more than can be presented in the current paper and does not promise to have any significant bearing on the question of a plurality of persons in the Godhead.

15 William David Reyburn and Euan McG. Fry, A Handbook on Genesis, UBS Handbook Series (New York: United Bible Societies, 1998), 50, explain that this involves a speaker "conferring or consulting with himself."

16 In accord with my introductory comments, it behooves the interpreter to treat these references as potential implications of plurality, not as any specifically Trinitarian statements.

17 S. R. Driver, The Book of Genesis, with Introduction and Notes (New York: Edwin S. Gorham, 1904), 14, remarks that God adopts "this unusual and significant mode of expression" in order to introduce the account of man's creation with solemnity. Bill T. Arnold, Genesis, NCBC (Cambridge, UK: Cambridge University Press, 2009), 44, agrees that the "lofty words of v. 26 make this event distinctive ...." John Peter Lange, Genesis or, the First Book of Moses, trans. by Tayler Lewis and A. Gosman, Commentary on the Holy Scriptures (1864; electronic ed., Bellingham, WA: Logos Bible Software, 2008), 173 lists five different ways to understand these first person plurals, but concludes that the carrying of the plural 
understanding of who God is, what deeds God has performed (both in creation and in setting about to redeem fallen mankind), who man is, and what man has caused by his disobedience to his Creator. Such plural pronouns occur one time outside Genesis (Isa 6:8, "Then I heard the voice of the Lord saying, 'Whom shall I send, and who will go for us?"'). In my opinion, these OT occurrences might be favorably compared with the use of the first person plural in NT passages like John 14:23, "Jesus answered and said to him, 'If anyone love Me, he will keep My word; and My Father will love him, and We will come to him and make Our abode with him"' (emphasis mine). It might be argued that Jesus purposefully echoes the language of the three Genesis texts to highlight His own deity. But, let's not use such NT references to interfere in a contextual examination of the text in Genesis.

\section{Genesis 1:26}

Commentators and theologians have proposed as many as seven different views of the plural pronouns ("us ... our ... our") in this text: ${ }^{18}$

(1) taken from a polytheistic account without correcting it $^{19}$

(2) refers to God plus the heavens and the earth ${ }^{20}$

(3) refers to the angelic beings in heaven's court - the most popular view currently and one that groups all such occurrences into the same category (Gen 1:26; 3:22; 11:7; Isa $6: 8)^{21}$

into "our image" might more accurately point to "a distinction in the divine personality." Hebraists point out that the so-called "plural of majesty" applies primarily to nouns and that it is uncertain whether that applies also to plural verbs or pronouns; cf. James McKeown, Genesis, THOTC (Grand Rapids: William B. Eerdmans Publishing Co., 2008), 26; Paul Joüon, A Grammar of Biblical Hebrew, trans. and rev. by T. Muraoka, 2 vols., Subsidia Biblica 14/I-II (Rome: Pontifical Biblical Institute, 1993), 2:376 (\$114e n. 1).

18 Victor P. Hamilton, The Book of Genesis Chapters 1-17, NICOT (Grand Rapids: William B. Eerdmans Publishing Co., 1990), 133-34; C. John Collins, Genesis 1-4: A Linguistic, Literary, and Theological Commentary (Phillipsburg, NJ: P \& R Publishing, 2006), 59-61. R. R. Reno, Genesis, Brazos Theological Commentary on the Bible (Grand Rapids: Brazos Press, 2010) discusses only the matter of what the "image" is, nothing about the plural pronouns.

${ }_{19}$ Herman Gunkel, Genesis, HKAT 1/1, 6th ed. (Göttingen, Germany: Vandenhoeck \& Ruprecht, 1963), 111; George A. F. Knight, A Christian Theology of the Old Testament, Biblical and Theological Classics Library (1959; repr., Carlisle, UK: Paternoster Publishing, 1998), 12 13, which he attributes to a henotheistic-one among many - view of God at the time of the J document of the Pentateuch.

20 W. Caspari, "Imago Divina," in Festschrift Reihold Seeberg, ed. W. Koepp (Leipzig, Germany: A. Deichert, 1929), 1:207; Waltke, Genesis, 64-65 (arguing that 3:22 and 11:7 do not appear to be a plurality in the Godhead either). Kenneth A. Mathews, Genesis 1-11:26, NAC 1A (Nashville, TN: Broadman \& Holman Publishers, 1996), 161 points out that v. 27 ("God created man") contradicts this view-God alone is the Creator. 
(4) a plural pronoun used when addressing oneself-a plural of deliberation: ${ }^{22}$ Collins believes that this opens the possibility of referring to a plurality of persons in the Godhead. ${ }^{23}$ However, Mathews finds this viewpoint lacking because there is no evidence that the plural is used this way in Hebrew. ${ }^{24}$ In fact, being cognizant of such absence of evidence, Cassuto adopts "the plural of exhortation" even though that explanation is "rejected by the majority of contemporary commentators." 25

(5) a plural pronoun of "majesty" - a royal "we": McKeown remarks that Hebrew nouns might be used this way, but there is insufficient evidence for pronouns and verbs with this sense in Biblical Hebrew. ${ }^{26}$ Likewise, Payne says that "The socalled 'royal we' usage is foreign to Old Testament thought." ${ }^{27}$ Hebraists point out that the so-called "plural of majesty" applies primarily to nouns and that it is uncertain whether that applies also to plural verbs or pronouns. ${ }^{28}$ Mathews argues that this view "is flawed since the point of the verse is the unique correspondence between God and man, not the majesty of God." 29

(6) a plural of fullness ${ }^{30}$

(7) a duality (I-Thou) in the Godhead ${ }^{31}$

(8) a plurality of divine persons = potential Trinitarian reference ${ }^{32}$

${ }^{21}$ See Bruce K. Waltke, An Old Testament Theology: An Exegetical, Canonical, and Thematic Approach, with Charles Yu (Grand Rapids: Zondervan, 2007), 212-15; Wenham, Genesis 1-15, 27-28, 85, 241; Patrick D. Miller, Jr., Genesis 1-11: Studies in Structure and Theme, JSOTSup 8 (Sheffield, UK: University of Sheffield, 1978), 9-26.

22 Westermann, Genesis 1-11, 145 represents this view. Thomas A. Keiser, "The Divine Plural: A Literary-Contextual Argument for Plurality in the Godhead," JSOT 34, no. 2 (2009): 131-46 this view suffers by finding very few analogies in Hebrew syntax and by its possible examples being questionable.

${ }^{23}$ Collins, Genesis 1-4, 59.

${ }^{24}$ Mathews, Genesis 1-11:26, 161.

${ }^{25}$ U. Cassuto, A Commentary on the Book of Genesis - Part I: From Adam to Noah, Genesis I-VI 8, trans. by Israel Abrahams (1961; repr., Jerusalem: Magnes Press, 1998), 55.

${ }^{26}$ McKeown, Genesis, 16.

27 J. Barton Payne, The Theology of the Older Testament (Grand Rapids: Zondervan Publishing House, 1962), 167.

${ }^{28}$ Joüon, A Grammar of Biblical Hebrew, 2:376 (\$114e n. 1).

${ }^{29}$ Mathews, Genesis 1-11:26, 161.

${ }^{30}$ G. Hasel, "The Meaning of 'Let Us' in Gn 1:26," AUSS 13 (1975): 65, 58-66.

${ }^{31}$ Karl Barth, The Doctrine of Creation, trans. by J. W. Edwards, O. Bussey, and Harold Knight, Church Dogmatics (Edinburgh: T. \& T. Clark, 1958), 60. 
One's theological view of Scripture impacts how he might approach this problem and seek a solution. For someone who believes that a human being wrote Genesis 1 without any divine revelation, the text might explain the origin of mankind only from the author's worldview. However, if the interpreter believes that Scripture's primary author is God Himself and that the record presents an accurate account from the Creator's perspective, then the words fall within a totally different kind of context. ${ }^{33}$ Indeed, since no man was present to hear these words when they were spoken, they can only be accurate if God Himself revealed them to the human author after the fact. Like Merrill, I affirm the Mosaic authorship of the Pentateuch and the conviction that God gave Moses revelation with regard to what he recorded. ${ }^{34}$

The heavenly council viewpoint depends heavily upon extra-biblical references in ANE literature to a council of heavenly beings. In other words, as Keiser notes, this approaches the issue from outside the immediate biblical context. ${ }^{35}$ According to Collins, some Bible scholars view any Trinitarian reference to be "ill-suited to the Old Testament or anachronistic." 36 However, Collins points to five arguments that support a plurality of persons in the Godhead: (1) Genesis 1:27 declares that God created the man "in the image of God"-a limited reference omitting any indication of anyone outside the Godhead; ${ }^{37}(2)$ the verbs "create" and "make" throughout the Creation account take God alone as their subject; (3) a parallel usage of the first person plural pronoun with regard to God occurs in Genesis 11:7 together with 11:8 identifying God alone as the actor; (4) inserting a council of angels does not fit well with other biblical references to such a council; and (5) a plurality of divine persons can be seen already with the reference to the Spirit of God in Genesis 1:2. ${ }^{38}$ Yet, instead of accepting the plurality of persons

32 Anthony A. Hoekema, Created in God's Image (1986; repr., Grand Rapids: William B. Eerdmans Publishing Co., 1994), 12; Paul R. House, Old Testament Theology (Downers Grove, IL: InterVarsity Press, 1998), 62; Bryan Murphy, "The Trinity in Creation," MSJ 24, no. 2 (Fall 2013): 167-77.

33 This is essentially the argument that Hoekema, Created in God's Image, 126 makes in regard to the accuracy of Moses's account of what happened at the fall in Gen 3.

${ }^{34}$ Eugene H. Merrill, "A Theology of the Pentateuch," in A Biblical Theology of the Old Testament, ed. by Roy B. Zuck (Chicago: Moody Press, 1991), 8.

35 Keiser, "The Divine Plural," 134: "That is, not finding any clue within the Genesis account to indicate the referent, those who hold this position take recourse to something which was likely sufficiently prominent in the world view of the original author and reader that it would be unnecessary to provide an explicit clarification."

${ }^{36}$ Collins, Genesis 1-4, 60.

37 Waltke, An Old Testament Theology, 215 takes the view that the overall record focuses on correspondence to God alone as the greater of those to which the plural pronoun refers (primus inter pares).

38 Amazingly, Cassuto, A Commentary on the Book of Genesis-Part I, 25 attributes the Gen 1:2 reference to "the paternal care of the Divine Spirit, which hovered over" the 
in the Godhead as the author's intended meaning, Collins prefers to limit it to sensus plenior which makes it possible to use 1:26 as a text that allows for the Trinity. ${ }^{39}$

Cassuto argues against the popular angelic council interpretation by also pointing to the text focusing on God alone as the Creator of mankind. Then he reasons that "Let us make" cannot be understood as consultation, because

if the intention was to tell us that God took counsel, the Bible would have explicitly stated whom He consulted, as we are told in other passages that are usually cited in support of this theory (I Kings xxii 19; Isa. vi 2-8; Job i-ii). ${ }^{40}$

After disavowing the heavenly council of angels view, Mathews concludes that Genesis 1:26 ("our image") together with v.27 ("His image") implies both the plurality (most immediately by reference to the Spirit of God in v. 2) and the unity of God. ${ }^{41}$ This is basically the same position that Hamilton takes, who concludes his thought with the following cautionary statement:

It is one thing to say that the author of Gen. 1 was not schooled in the intricacies of Christian dogma. It is another thing to say he was theologically too primitive or naive [sic.] to handle such ideas as plurality within unity. What we often so blithely dismiss as "foreign to the thought of the OT" may be nothing of the sort. ${ }^{42}$

Let's take a closer look at the structure of vv. 26-27 to see if it might provide some additional information that might be of help (blue marks singulars; red marks plurals):

26 Then God said,

Let us make man in our image, according to our likeness; and let them rule over the fish of the sea and over the birds of the sky and over the beasts and over all the earth,

primeval waters at creation. He does not state that the Spirit is a person of the Godhead and, indeed, elsewhere implies that it might be the breath of God by taking the meaning as identical to Job 33:4 ("The spirit of God has made me, and the breath of the Almighty gives me life"; ibid., 24). He makes the non-personal identification more specific in his discussion of 6:3 ("My spirit, the spirit of life that I breathed into man's nostrils, shall not abide in man forever"; ibid., 296). Hamilton, Genesis Chapters 1-17, 114 concludes that the text does not indicate a specific viewpoint, therefore, to "translate 'Spirit' runs the risk of superimposing Trinitarian concepts on Gen. 1 that are not necessarily present." See Waltke, An Old Testament Theology, 212-13 for an example of a treatment of this issue by a theologian who rejects any association of "the Spirit of God" in the OT with a person of the Godhead. Waltke takes references to "the spirit of God/Yahweh" as references to God's power which He did not reveal as the Holy Spirit (as a divine person) until the coming of Christ (ibid., 619).

${ }^{39}$ Collins, Genesis 1-4, 61.

${ }^{40}$ Cassuto, A Commentary on the Book of Genesis - Part I, 55.

${ }^{41}$ Mathews, Genesis 1-11:26, 163.

${ }^{42}$ Hamilton, Genesis Chapters 1-17, 134. 
27 God created man

and over every creeping thing that creeps on the earth."

in His image,

in the image of God

He created him;

male and female He created them.

Let's put it into a table:

\begin{tabular}{|c|c|c|c|}
\hline \multicolumn{2}{|c|}{ Divine References } & \multicolumn{2}{c|}{ Human References } \\
\hline Singular & Plural & Singular & Plural \\
\hline God said & & man & \\
\hline & Let us make & & let them rule \\
\hline & in our image & & \\
\hline & our likeness & & \\
\hline God created & & man & \\
\hline in His image & & & \\
\hline He created & & him & \\
\hline He created & & & male and female \\
\hline & & & them \\
\hline
\end{tabular}

The text makes three plural statements about God and three about man. Three times "man" appears in the singular. Three times "created" is used in the singular. Three different singular statements are made about God ("God said," "God created," "in His image"). ${ }^{43}$ In addition, v. 27 is a poetic triplet with the first two cola being formed chiastically. ${ }^{44}$ Therefore, the text presents the unity and plurality of both God and man. This exegetical result must be taken into account. As Keiser suggests, the "singular and plural terminology provides a strong argument for understanding a connection between the two." ${ }^{45}$ If this account existed as an oral tradition in the post-Fall world, we must assume that the hearers had the mental acuity to think about the parallels here between God and man-especially in light of 2:24 (a man and his wife "become one flesh"). If God only revealed this account at a much later date to Moses, we still must assume (unless we have an anti-Semitic prejudice treating the Jews as dullards and incapable of sound thinking) that this text stimulated the Israelites' thinking as they contemplated the reasons for such unity, yet plurality, for both God and man. Keiser makes yet

43 Emphatic triplets characterize the account of the sixth day: Three times "God said" (vv. 24, 26, 29) -the tautology of "God blessed . . and said" (v. 28) should be taken as one emphatic declaration of blessing. The blessing itself contains a triplet: "be fruitful . . . multiply ... fill."

44 Verse 26 can stand as evidence for the poetic prose (elevated narrative) that makes up much of the Creation account. The insertion of v. 27 as pure poetry will be matched later by $2: 23$.

${ }^{45}$ Keiser, "The Divine Plural," 135. 
another contribution to the analysis of the singular and plural in 1:26-27 when he notes that the transition from singular to plural occurs in a context of generating life. ${ }^{46}$

\section{Theophanies in Genesis}

"The angel/Angel of Yahweh" (דאלמ הי דזָ, mal'ak yhwh) appears in Genesis 16 (vv. 7, 9-11; 22:11, 15). At times both narrator and speakers within the events identify him with Yahweh (16:13). The angel/messenger can speak in the first person, as though he were God (16:10). Therefore, many commentators and theologians identify this individual as an appearance of God Himself, a theophany. ${ }^{47}$ Knight lists the following theophanies in Genesis: 16:7-14; 18:1-22; 19; 21:17-19; 22:11-18; 31:11-13; 32:24-30; and, 48:15-16. ${ }^{48}$ However, he explains them all away as not being God Himself in

person, but only an "alter ego' of himself." ${ }^{49}$ Still, he is forced to admit that a number of these texts specifically identify that presence on earth as God (21:18; 22:14; 31:13). These texts have fallen prey to the same frame of mind that treats Genesis 1 as nothing more than sanctified human imagination. As Moberly points out, theologians have given up on the traditional Christian understanding that the theophany in these chapters indicates a plurality of persons in the Godhead. Why have they given up? - it "naturally fell by the wayside when the text was approached in a historical-critical frame of reference."

\section{Genesis 16:7-14}

In this passage the narrator (Moses) himself (not Hagar) identifies the angel of Yahweh as Yahweh ("Then she called the name of Yahweh who spoke to her,"; v. 13). According to Wenham, the text's referent involves "God himself appearing in human form." ${ }^{51}$ However, Waltke takes the angel as merely a surrogate for God who is treated as God, but remains distinct from God-he is but a messenger whom God sends out of the heavenly council of

46 Ibid., 138. He also associates the transition from singular to plural with the image of God. Since the topic of this paper is more limited, I will not develop this aspect of the text.

${ }^{47}$ Kenneth A. Mathews, Genesis 11:27-50:26, NAC 1B (Nashville, TN: Broadman \& Holman Publishers, 2005), 188-89.

${ }^{48}$ Knight, A Christian Theology of the Old Testament, 63-65.

${ }^{49}$ Ibid., 67.

${ }^{50}$ R. W. L. Moberly, The Theology of the Book of Genesis, Old Testament Theology, ed. by Brent A. Strawn and Patrick D. Miller (2009; repr., Cambridge, UK: Cambridge University Press, 2013), 223-37.

51 Wenham, Genesis 16-50, 9. 
angelic beings. ${ }^{52}$ Waltke ignores the statement "Yahweh who spoke to her" (הוהי רבזה הילא, v. 13). It seems clear by context that Hagar is addressing "the angel of Yahweh" who had just been speaking to her (vv. 11-12). Merrill also identifies "the angel of Yahweh" as a surrogate, rather than being a person of the Godhead. ${ }^{53}$

\section{Genesis 18-19}

The opening words of this text unit ("Yahweh appeared to him at the oaks of Mamre," 18:1) point to Moses's narration of the events in these two chapters. Abraham himself did not at first realize that one of the three men at his tent door was actually Yahweh. ${ }^{54}$ Wenham observes that when "the angel of Yahweh" appears together with other individuals, at first "they are usually taken to be men, but by the end of the encounter one of them is realized to be God (18:2, 22; Judg 6:11-22; 13:3-22)." "55 Even if one were to identify the description of the three individuals (two angels plus a person of the Godhead) as anthropomorphism, that does not require that the entire narrative, together with the identification of the three individuals, "be dismissed as merely figurative or symbolic." 56 Those who accept the occurrence of a theophany here do so, in at least some cases, even if they deny that a theophany occurred in chapter $16^{57}$

In addition to the theophany that seems so apparent in chapter 18, 19:24 says, "Then Yahweh rained upon Sodom and upon Gomorrah sulfurous fire from Yahweh, from the heavens." By placing "Yahweh" at the head of the clause, the Spirit-superintended author emphasizes the Lord's role in the event. As Ross puts it, "The text . . . simply emphasizes that, whatever means were used, it was the Lord who rained this judgment on them." 58 While this is an accurate

52 Waltke, Genesis, 254.

53 Merrill, Everlasting Dominion, 77 refers to $18: 1$ as a reference to "the Lord's appearance ... in a tangible form in the person of the angel of the Lord who, in fact, is equated with the Lord himself (Gen. 18:10, 13, 17, 20, etc.)." But, a few pages later states that this personage "appears, either as a representative of the Lord or, in a few instances, as his surrogate" (ibid., 80-81). He reasons that there is no basis in the OT for taking this individual as the preincarnate Christ, but he is merely "a superhuman spokesman for the Lord himself" (ibid., 81; see also, 83-84).

${ }^{54}$ Wenham, Genesis 16-50, 45 makes this observation.

55 Wenham, Genesis 16-50, 9.

56 Hoekema, Created in God's Image, 127. Hoekema's argument for the integrity of the narrative seeks to respond to those, unlike himself, who think that the author identified the individuals using a mere anthropomorphism, rather than intending that they actually possessed the physical forms of men.

57 Waltke, Genesis, 266 is just such an example.

${ }^{58}$ Allen P. Ross, Creation and Blessing: A Guide to the Study and Exposition of Genesis (Grand Rapids: Baker, 1996), 362. 
observation, it is only one part of the overall meaning of this clause. There is a second occurrence of "Yahweh" later in the verse: "from Yahweh." Is the second mention of Yahweh merely a redundant expression in order to extend the emphasis of the first word, or is it the result of Moses' careful attention to theological detail? ${ }^{59}$

REB, NLT, and NJB chose to eliminate the second reference to Yahweh as being a redundant expression. In his commentary Wenham opts for a similar conclusion but for different reasons. He believes that the "narrator stresses that 'it was from the LORD." However, Wenham translates the verse as follows: "and the LORD rained brimstone and fire on Sodom and Gomorrah: it was from the LORD from the sky." ${ }^{\circ 0}$ This represents a legitimate attempt to translate the text as it stands. It also takes into account the Masoretic accents dividing the verse. However, the treatment of this final portion of the verse as a noun clause (viz., "it was") lacks convincing grammatical evidence. Instead, it would be more natural grammatically to take these last two phrases as adverbial prepositional phrases modifying the main verb, "rained."

Most translations obscure the presence of two different persons of the Godhead. If the expression were an intentional redundancy, one would expect to see it used elsewhere in the OT. However, it does not occur elsewhere. This is a unique expression that is clarified by later revelation. The OT reveals that in a number of cases the "angel of Yahweh" was the immediate agent of judgment (cf. 2 Sam 24:16-17; 2 Kgs 19:35; Ps 35:6-7). Therefore, it is no surprise that the same agency might apply in the judgment of Sodom and Gomorrah.

Genesis 19:24 strikes at the heart of aberrant theology found in some cults like the Jehovah's Witnesses. This verse identifies two persons with the title of Yahweh-one in heaven above and one with a presence nearer to or upon the earth. In his Systematic Theology Strong places this text alongside Hosea 1:7 and 2 Timothy 1:18 as examples of passages in which "Jehovah distinguishes himself from Jehovah." ${ }^{61}$ Likewise, Borland points to the same distinction of persons in Genesis 19:24. ${ }^{62}$ In his commentary Hamilton argues that the

${ }^{59}$ See my study of this passage: William D. Barrick, “The Integration of OT Theology with Bible Translation," MSJ 12, no. 1 (Spring 2001): 26-29.

${ }^{60}$ Wenham, Genesis 16-50, 35.

${ }^{61}$ Augustus Hopkins Strong, Systematic Theology: A Compendium Designed for the Use of Theological Students, 3 vols. in 1 (1907; repr., Valley Forge, PA: Judson Press, 1967), 318.

62 James A. Borland, Christ in the Old Testament, rev. ed. (Ross-shire, UK: Christian Focus, 1999), 152. Others who note this same distinction in the text include David L. Cooper, The God of Israel, rev. ed. (Los Angeles: Biblical Research Society, 1945), 23. Oehler granted that some sort of distinction was being made in Gen 19:24 but did not think that, in and of itself, it supported the view of identifying the one manifestation directly with the Logos, the Son of God, the second person of the Godhead; Gustav Friedrich Oehler, Theology of the Old 
phraseology is not to be "dismissed as a doublet or a gloss." ${ }^{63}$ However, he stops short of noting any distinction between divine persons in the passage. Were the translators of REB, NLT and NJB anti-Trinitarian? If so, that cannot be determined by the translation alone. A theologically insensitive translation does not reveal anything about the theological position of the translators. The translation might indicate that a particular theological conclusion was not sufficiently clear to the translators in a particular passage. It is irresponsible to stigmatize the translators with a particular theological error or heresy on the basis of a single passage's translation. Do such translations weaken the evidence supporting a particular doctrine? They might, but that is not the same as outright denial of the doctrine in question. Even though prejudice may be implied by a particular translation, that one translation rarely affects the readers' broad conclusions about doctrine when they study a particular theological point through the entire version in which the one translation appears. One questionable translation in one passage might mislead someone on a few occasions, but in almost every case the same reader can formulate a theological opinion from the full version that generally results in sound doctrine.

\section{Genesis 21:17-19}

This passage does not exhibit the same clarity as the previous two passages. First of all, "the angel of God" (v. 17) occurs, not "the angel of Yahweh." ${ }^{64}$ Secondly, the angel states that "God has heard the voice of the lad" (v. 17). Thirdly, v. 19 indicates that "God opened her eyes," but does not require that He be present. Wenham points out the similarities with 22:11, 15 to indicate that the two personages were probably identical - neither descended to earth. ${ }^{65}$ The ambiguity makes it difficult to categorize this event as a clear theophany-there is no seeing or

Testament, trans. George E. Day (1883; repr., Minneapolis, MN: Klock \& Klock, 1978), 133. Herman Bavinck, The Doctrine of God, trans. and ed. by William Hendriksen (1977; repr., Edinburgh: Banner of Truth Trust, 1997), 258 cites Gen 19:24 as important OT passages indicating "a distinction within the Divine Being."

63 Victor P. Hamilton, Genesis: Chapters 18-50, NICOT (Grand Rapids: William B. Eerdmans Publishing Co., 1995), 46. Westermann is representative of those who think that the repetitive reference to Yahweh is awkward and due to a merging of two different accounts; Claus Westermann, Genesis 12-36: A Commentary, trans. John J. Scullion (Minneapolis, MN: Augsburg Press, 1985), 306

${ }^{64}$ Waltke, Genesis, 296. He suggests that the phrase use of "the angel of God" (as opposed to "the angel of Yahweh") resulted from the fact that the angel is addressing the non-elect here

${ }^{65}$ Wenham, Genesis 16-50, 85 
appearing, only speaking and hearing. Waltke's brief summary indicates the same view he had taken on chapter 16 (though he only refers to 22:1, 15- and there he does refer back to 16:7). ${ }^{66}$

\section{Genesis 22:11-18}

Representing one view of this text, Wenham assumes a theophany here on the basis of the phraseology employed and the use of ra'ah in the name of the mountain (Moriah). The verb characterizes prior appearances of God to Abraham (12:7; 17:1; 18:1), linking the Moriah event to Abraham's past experiences. ${ }^{67}$

\section{Genesis 31:11-13}

Again "the angel of God" occurs in place of "the Angel of Yahweh" (see 21:17; 28:12; 32:2). Waltke implies by his reference back to $16: 7$ that he takes this appearance as a surrogate for God, not God Himself. ${ }^{68}$ However, that view seems to ignore the self-identifying

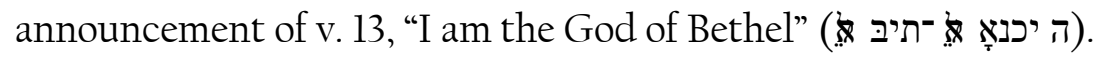

\section{Genesis 32:24-30 (Heb. 25-31)}

The mysterious nature of the account regarding Jacob and his wrestling opponent at the Jabbok River has spawned many different explanations. For those steeped in the evolution of natural religion and a denial of divine inspiration and biblical inerrancy, the explanations run the full gamut of conformity to the worldviews of pagan religions found in Israel's historical and cultural context. Wenham summarizes such views as follows,

Gunkel, von Rad, and Westermann are among those who suggest that originally this was an account of Jacob's encounter with a Canaanite river god. And this they hold is confirmed by the "man's" desire to depart before dawn, a regular feature of folk tale. However, as Eissfeldt (KS 3, 412-16) observed, the story actually identifies the opponent as El the supreme Canaanite creator god.... 69

Verse 28 (Heb. 29, "for you have struggled with God," תירש-יכּ םיהלא־ם) implies that the individual with whom Jacob had wrestled was God Himself. Jacob then confirms this fact by saying, "I have seen God face to face"70 (v. 30, Heb. 31, פיהלא םינפּ םינפּ־לא). The Lord had

${ }^{66}$ Waltke, Genesis, 296, 308.

${ }^{67}$ Wenham, Genesis 16-50, 111

${ }^{68}$ Waltke, Genesis, 296, 425

${ }^{69}$ Wenham, Genesis 16-50, 295

70 Waltke, Genesis, 447 notes that "face to face" appears in the Hebrew Bible "only of direct divine-human encounters, not necessarily of literal visual perception." 
appeared to Jacob, as He had to Abraham (Gen 18:1-2), in the physical form of a man. ${ }^{71}$ Although he does not spend much time discussing the theophanies in Genesis, Brueggemann does finally indicate that the "angel" appearances in chapters 18 and 32 did indeed involve God just as certainly as $48: 15-16 .^{72}$

\section{Genesis 48:15-16}

On one hand, Knight includes this text as a potential theophany solely on the basis of implications gained from later revelation in Isaiah that indicate that God alone acts as the Redeemer of Israel (e.g., Isa 43:14; 44:6, 24; 47:4). ${ }^{73}$ On the other hand, Wenham relies upon prior textual references and repetitions within the current passage to establish the identity of "the angel who has redeemed" Jacob. ${ }^{74}$ First, God Himself had rescued Jacob from both his uncle (Gen 31:42) and his brother (Gen 32-33). Second, Jacob's triple declaration parallels and equates God with the angel:

The God before whom my fathers Abraham and Isaac walked,

The God who has been my shepherd all my life to this day,

The angel who has redeemed me from all evil, ... (48:15-16a, emphasis mine $)^{75}$

Third, Jacob calls upon this individual (identified by the triple statement) to bless Ephraim and Manasseh, Joseph's two sons (v. 16b). ${ }^{76}$

\section{Result: Summary Regarding Theophany in Genesis}

Such theophanies seem to possess one significant feature: all of them "reveal, at least in a partial manner, something about [God] Himself, or His will, to the recipient. ${ }^{77}$ Should we identify the divine person in such appearances as the pre-incarnate Son of God (i.e., a Christophany)? James Borland's definition of "Christophany" runs as follows: "those unsought,

${ }^{71}$ See Hoekema, Created in God's Image, 127 regarding the possible use of anthropomorphism, as mentioned above in $\mathrm{fn} 30$.

72 Brueggemann, Genesis, 362

${ }^{73}$ Knight, A Christian Theology of the Old Testament, 64-65

${ }^{74}$ Wenham, Genesis 16-50, 465.

${ }^{75}$ Waltke, Genesis, 599 takes the parallelism as a strong indicator that, unlike in 16:7, the angel is God Himself. Brueggemann, Genesis, 361 notes the same three parallels and adds a fourth: "God make you" (v. 2). He emphasizes that this God is the focus of the text and all the verbs describe His actions (ibid., 362).

${ }^{76}$ Jacob's request ("Bless") consists of a jussive 3ms (בי די (ד), not a plural, which might be expected if God and the angel were two separate beings.

77 Borland, Christ in the Old Testament, 24. 
intermittent and temporary, visible and audible manifestations of God the Son in human form, by which God communicated something to certain conscious human beings on earth prior to the birth of Jesus Christ." ${ }^{78}$ When the biblical account associates "the angel of Yahweh" with a theophany, "messenger" might be a better translation than "angel," because this title denotes the function or office of the individual, not His nature. ${ }^{79}$ In addition, He is spoken of as actually being God, He bears the name Yahweh, He speaks as God, He displays divine attributes and authority. Most significantly, however, He receives worship. ${ }^{80}$

Shedd identifies twelve actions and relations that serve as evidence to distinguish between persons of the Godhead. ${ }^{81}$ One of the twelve Shedd identifies involves the persons of the Godhead conferring with one another as in Genesis 1:26 and 11:7. Genesis 1:1-2 also potentially depicts two divine persons working together at the creation of the heavens and the earth. Among the Genesis texts describing theophanies, 19:24 describes one Yahweh residing in heaven working in concert with the theophanic Yahweh upon the earth to bring judgment upon Sodom and Gomorrah. Thus, three different evidences in Genesis point to a distinction of divine persons. Then there is the example of one person of the Godhead speaking about another, as in 6:3, "Then Yahweh said, 'My Spirit shall not strive with mankind forever ..."

Putting all of these Genesis references together, we can reach a conclusion similar to that of Oehler: "Though we must not read the New Testament doctrine of the Trinity into the Old Testament, it is yet undeniable that we find the way to the economic Trinity of the New Testament already prepared in the doctrine of the Malakh and of the Spirit." 82

\section{Conclusion}

This study of the Trinity in the book of Genesis has produced for our consideration the following findings:

1. A suggestion that there might be a plurality of persons in the Godhead appears almost immediately in the text with Genesis l:1 referring to God and v. 2 referring to "the Spirit of God."

78 Borland, Christ in the Old Testament, 17.

79 Borland, Christ in the Old Testament, 36.

80 Borland, Christ in the Old Testament, 37-42.

81 Shedd, Dogmatic Theology, 1:279, "One divine Person loves another, John 3:35; dwells in another, John 14:10, 11; suffers from another, Zach. 13:7; knows another, Matt. 11:27; addresses another, Heb. 1:8; is the way to another, John 14:6; speaks of another, Luke 3:22; glorifies another, John 17:5; confers with another, Gen. 1:26, 11:7; plans with another, Isa. 9:6; sends another, Gen. 16:7, John 14:26; rewards another, Phil. 2:5-11; Heb. 2:9."

82 Oehler, Theology of the Old Testament, 142 
2. The plurality gains a stronger indicator by the three passages in which the first person plural pronouns occur (1:26; 3:22; 11:7).

3. When 6:3 depicts one person of the Godhead speaking about another, the evidence continues to grow.

4. Then 19:24 describes two Yahwehs working together from two different locations in the judgment of Sodom and Gomorrah. That presents an increasingly convincing amount of evidence for the plurality of divine persons in the book of Genesis

5. Lastly, "the angel/messenger of Yahweh" in the theophanies of chapters 16, 18-19, $21,22,31,32$, and 48 strengthen the evidence with their overwhelming testimony to three potential candidates for divine persons: (1) God/Yahweh $\# 1$, (2) the Angel / Yahweh \#2, and (3) the Spirit of God \$3.

No one should interpret these evidences as a clear declaration of the Trinity in the same terms with which the NT does. However, the book of Genesis provides significant information regarding a plurality of persons in the Godhead at work on earth and with mankind in the prepatriarchal and patriarchal periods. As a matter of fact, it is possible that a study of the book of Job, which also dates from the patriarchal period, might present some of the same evidences and reach similar conclusions. ${ }^{83}$

\section{Bibliography}

Albertz, R., and C. Westermann. "חוּר rûh spirit." In Theological Lexicon of the Old Testament, 3 vols., ed. by Ernst Jenni and Claus Westermann, trans. by Mark E. Biddle. Peabody, MA: Hendrickson Publishers, 1997. 3:1202-20.

Arnold, Bill T. Genesis. New Cambridge Bible Commentary. Cambridge, UK: Cambridge University Press, 2009.

Barker, Kenneth L. “Zechariah.” In The Expositor's Bible Commentary, rev. ed., 13 vols.,ed. by Tremper Longman III and David E. Garland. Grand Rapids: Zondervan,2008. 8:721-833.

Barrick, William D. "Conscience, Oral Tradition, Natural Religion, or Later Insertion?: Unwritten Revelation in Genesis 1-1l.” Evangelical Theological Society Annual Meeting, San Francisco, 2011.

83 For some preliminary studies related to this topic, see William D. Barrick, "Messianic Implications in Elihu's 'Mediator Speech' (Job 33:23-28)" (unpublished paper presented at National ETS Meetings, Atlanta, November 19, 2003). 
Barrick, William D. "Inspiration and the Trinity." Master's Seminary Journal 24, no. 2 (Fall 2013):179-97.

Barrick, William D. "The Integration of OT Theology with Bible Translation.” Master's Seminary Journal 12, no. 1 (Spring 2001): 15-31.

Bavinck, Herman. The Doctrine of God. Translated and edited by William Hendriksen. 1977. Reprint, Edinburgh: Banner of Truth Trust, 1997.

Bernard, J. H. A Critical and Exegetical Commentary on the Gospel According to St.John. 2 volumes. Edited by Alan Hugh McNeile. International Critical Commentary. Edinburgh: T \& T Clark, 1929.

Block, Daniel I. "How Many Is God? An Investigation into the Meaning of Deuteronomy 6:4-5." Journal of the Evangelical Theological Society 47, no. 2 (June 2004):193-212.

Boice, James Montgomery. Foundations of the Christian Faith: A Comprehensive \& Readable Theology. Revised edition. Downers Grove, IL: InterVarsity Press, 1986.

Borland, James A. Christ in the Old Testament. Revised edition. Fearn, UK: Mentor, 1999.

Bowman, Robert M., Jr. et al. The Trinity. Torrance, CA: Rose Publishing, 1999. Brown, Raymond E. The Gospel According to John (XIII-XXI): Introduction, Translation, and Notes. Anchor Yale Bible 20A. 1974. Reprint, New Haven, CT: Yale University Press, 2008.

Burrows, Millar. An Outline of Biblical Theology. Philadelphia: Westminster, 1946. Chafer, Lewis Sperry. Systematic Theology. 8 volumes. 1947. Reprint, Dallas: Dallas Seminary Press, 1969.

Chester, Tim. Delighting in the Trinity: Why Father, Son and Spirit are Good News. Revised 2nd edition. 2010. Reprint, Purcellville, VA: Good Book Company, 2013.

Cooper, David L. The God of Israel. Revised edition. Messianic Series. Los Angeles: Biblical Research Society, 1945.

Driver, S. R. The Book of Genesis, with Introduction and Notes. New York: Edwin S. Gorham, 1904.

Erickson, Millard J. Christian Theology. Grand Rapids: Baker Book House, 1985

Feinberg, John S. No One Like Him: The Doctrine of God. Foundations of Evangelical Theology. Wheaton, IL: Crossway Books, 2001. 437-98.

Fretheim, Terence. "Yahweh." In New International Dictionary of Old Testament Theology \& Exegesis, 5 vols., ed. by Willem A. VanGemeren. Grand Rapids: Zondervan Publishing House, 1997. 4:1295-1300.

Grisanti, Michael A. “Deuteronomy.” In The Expositor's Bible Commentary, 13 vols., rev. ed., ed. by Tremper Longman III and David E. Garland. Grand Rapids: Zondervan, 2012. 2:457-814. 
Grogan, Geoffrey W. "Isaiah.” In The Expositor's Bible Commentary, 12 vols., ed. by Frank E. Gaebelein. Grand Rapids: Zondervan Publishing House, 1986. 6:3-354.

Harris, R. Laird. "The Pronunciation of the Tetragram." In The Law and the Prophets: Old Testament Studies Prepared in Honor of Oswald Thompson Allis, ed. by John H. Skilton. N.p.: Presbyterian and Reformed Publishing Co., 1974. 215-24.

Hasel, G. "The Meaning of 'Let Us' in Gn 1:26.” Andrews University Seminary Studies 13 (1975): 5866.

Heiser, Michael S. "Should מיהלא ('ělōhîm) with Plural Predication Be Translated ‘Gods'?” Bible Translator 61, no. 3 (July 2010): 123-36.

Heiser, Michael S. "Theophany in the Old Testament.” In Faithlife Study Bible, by John D. Barry et al. Bellingham, WA: Logos Bible Software, 2012.

Hendriksen, William. Exposition of the Pastoral Epistles. New Testament Commentary. Grand Rapids: Baker Book House, 1957.

Hildebrandt, Wilf. An Old Testament Theology of the Spirit of God. Peabody, MA: Hendrickson Publishers, 1995.

Hubbard, Robert L., Jr., Robert K. Johnston, and Robert P. Meye, eds. Studies in Old Testament Theology. Dallas: Word Publishing, 1992.

Joüon, Paul. A Grammar of Biblical Hebrew. Translated and revised by T. Muraoka. 2 volumes. Subsidia Biblica 14/I-II. Rome: Pontifical Biblical Institute, 1993.

Keiser, Thomas A. "The Divine Plural: A Literary-Contextual Argument for Plurality in the Godhead." Journal for the Study of the Old Testament 34, no. 2 (2009): 131-46

Knight, George A. F. A Christian Theology of the Old Testament. Biblical and Theological Classics Library. 1959. Reprinted; Carlisle, UK: Paternoster Publishing, 1998.

Knox, Broughton. The Everlasting God. Kingsford, Australia: Matthias Media, 2009.

Lange, John Peter. Genesis or, the First Book of Moses. Translated by Tayler Lewis and A. Gosman. Commentary on the Holy Scriptures. Electronic edition. 1864. Bellingham, WA: Logos Bible Software, 2008.

McKeown, James. Genesis. Two Horizons Old Testament Commentary. Grand Rapids: William B. Eerdmans Publishing Co., 2008.

Merrill, Eugene H. Everlasting Dominion: A Theology of the Old Testament. Nashville: B\&H Publishing Group, 2006. 
Moberly, R. W. L. The Bible, Theology, and Faith: A study of Abraham and Jesus. Cambridge Studies in Christian Doctrine. Cambridge, UK: Cambridge University Press, 2000.

Murphy, Bryan. "The Trinity in Creation." Master's Seminary Journal 24, no. 2 (Fall 2013): 167-7

Niehaus, Jeffrey J. God at Sinai: Covenant and Theophany in the Bible and Ancient Near East. Studies in Old Testament Biblical Theology. Grand Rapids: Zondervan Publishing House, 1995.

Pache, René. The Inspiration and Authority of Scripture. Translated by Helen I. Needham. Chicago: Moody Press, 1969.

Payne, J. Barton. The Theology of the Older Testament. Grand Rapids: Zondervan Publishing House, 1962. 166-76.

Pink, Arthur W. Exposition of the Gospel of John. 3 volumes. 2nd edition. Grand Rapids: Zondervan Publishing House, 1958.

Reyburn, William David, and Euan McG. Fry. A Handbook on Genesis. United Bible Societies Handbook Series. New York: United Bible Societies, 1998.

Schaff, Philip, ed. The Nicene and Post-Nicene Fathers. Volume 3, St. Augustine: On the Holy Trinity, Doctrinal Treatises, Moral Treatises. Grand Rapids: Eerdmans, 1956.

Shedd, William G. T. Dogmatic Theology. 3 volumes. 1888. Reprint, Grand Rapids: Zondervan Publishing House, 1971.

Smith, Gary V. Isaiah 40-66. New American Commentary 15B. Nashville: Broadman \& Holman Publishers, 2009.

Sproul, R. C. "The Internal Testimony of the Holy Spirit." In Inerrancy, ed. by Norman L. Geisler. Grand Rapids: Zondervan Publishing House, 1980. 335-54.

Stanton, R. Todd. "Numbers 12:6-8: Its Contribution to the Study of Revelation and Theophany in the Old Testament." ThM thesis, The Master's Seminary, 2000.

Talbert, Charles H. Reading John: A Literary and Theological Commentary on the Fourth Gospel and the Johannine Epistles. Revised edition. Reading the New Testament Series. Macon, GA: Smyth \& Helwys Publishing, 2005.

Tengström, S., and H.-J. Fabry. "חזוּר rûah." In Theological Dictionary of the Old Testament, 16 vols., ed. by G. Johannes Botterweck, Helmer Ringgren, and Heinz-Josef Fabry, trans. by David E. Green. Grand Rapids: William B. Eerdmans Publishing Co., 2004. 13:365-402.

Verhoef, P. A. "Prophecy." In New International Dictionary of Old Testament Theology and Exegesis, 5 vols., ed. by Willem A. VanGemeren. Grand Rapids: Zondervan Publishing House, 1997. 4:1067-78. 
Waltke, Bruce K. An Old Testament Theology: An Exegetical, Canonical, and Thematic Approach. With Charles Yu. Grand Rapids: Zondervan, 2007.

Waltke, Bruce K. and M. O'Connor. An Introduction to Biblical Hebrew Syntax. Winona Lake, IN: Eisenbrauns, 1990.

Ware, Bruce A. "How Shall We Think About the Trinity?" In God Under Fire: Modern Scholarship Reinvents God, ed. by Douglas S. Huffman and Eric L. Johnson. Grand Rapids: Zondervan, 2002. 253-77.

Watts, Rikk E. "Mark." In Commentary on the New Testament Use of the Old Testament, ed. by G. K. Beale and D. A. Carson. Grand Rapids: Baker Academic, 2007. 111-249.

Young, Edward J. The Book of Isaiah. 3 volumes. New International Commentary on the Old Testament. Grand Rapids: Wm. B. Eerdmans Publishing Co., 1972.

Young, Edward J. My Servants the Prophets. 1952. Reprint, Grand Rapids: Wm. B. Eerdmans Publishing Co., 1971. 